\title{
In Vivo Effects of Naringenin and Lead on Rat Erythrocyte Carbonic Anhydrase Enzyme
}

\section{Naringenin ve Kurşunun Sıçan Eritrosit Karbonik Anhidraz Enzimi Üzerine In Vivo Etkileri}

\author{
Müslüm KUZU1*, Ahmet ÖZKAYA², Zafer ŞAHIN³3, Üzeyir DAĞ2, Veysel ÇOMAKLI ${ }^{4}$, Ramazan DEMIRDAĞ4 \\ 1Ağrı İbrahim Çeçen University, Faculty of Pharmacy, Ağrı, Turkey \\ 2Adıyaman University, Faculty of Arts and Sciences, Department of Chemistry, Adıyaman, Turkey \\ ${ }^{3}$ Necmettin Erbakan University, Faculty of Health Sciences, Department of Physiotherapy and Rehabilitation, Konya, Turkey \\ ${ }^{4}$ Ağrı Ibrahim Çeçen University, School of Health, Department of Nutrition and Dietetics, Ağrı, Turkey
}

\begin{abstract}
Objectives: Carbonic anhydrase (CA) enzyme catalyses the reversible reactions of $\mathrm{CO}_{2}$ with water and takes part in metabolically important events such as systemic acid-base regulation and respiration. In this study, in vivo effects of lead, which is a heavy metal and to which living beings are exposed by different ways, with naringenin, a flavanone, were investigated.

Materials and Methods: For this purpose, four different rat groups were established and one of them was chosen as the control group. The other three groups were given lead, naringenin and lead+naringenin substances to analyze the changes in the CA enzyme of rat erythrocytes.

Results: The research findings showed that the enzyme activity in the control group was higher than that in the other groups. The naringenin group showed the highest inhibition effect, while the lead group showed the lowest inhibition.
\end{abstract}

Conclusion:Therefore, it can be said that naringenin is a strong inhibitor of the CA enzyme.

Key words: Carbonic anhydrase, inhibition, lead, naringenin

öz

Amaç: Karbonik anhidraz (CA) enzimi $\mathrm{CO}_{2}$ 'nin su ile tersinir reaksiyonunu katalizler ve sistemik asit baz dengesi, solunum gibi metabolik açıdan oldukça önemli olaylarda görev alır. Bu çalışmada canlıların farklı yollarla maruz kaldığı bir ağır metal olan kurşun ile bir flavanon olan naringeninin enzim üzerine in vivo etkisi araştırıldı.

Gereç ve Yöntemler: Bu amaçla, dört farklı sıçan grubu oluşturuldu ve bunlardan biri kontrol grubu olarak belirlendi. Diğer üç gruba ise kurşun, naringenin ve kurşun+naringenin maddeleri verildi ve eritrositlerdeki CA enzim aktivitesindeki değişimler incelendi.

Bulgular: Araştırma bulguları kontrol grubundaki enzim aktivitesinin diğer gruplardan daha fazla olduğunu gösterdi. Kurşun grubu en düşük inhibisyon etkisini gösterirken, narigenin grubu en yüksek inhibisyon etkisini gösterdi.

Sonuç: Bu nedenle naringeninin CA enzimi için kuvvetli bir inhibitör olduğu söylenebilir.

Anahtar kelimeler: Karbonik anhidraz, inhibisyon, kurşun, naringenin

\section{INTRODUCTION}

Carbonic anhydrase (CA) is a metalloenzyme found in all organisms and it contains a $\mathrm{Zn}^{+2}$ ion in the active site (carbonate hydrolase E.C.4.2.1.1). Discovered first from cattle erythrocytes, $\mathrm{CA}$ is a significant enzyme which reversibly catalyzes $\mathrm{CO}_{2}$ hydration and $\mathrm{HCO}_{3}$ - dehydration reactions in living beings. 'This reaction is involved in imported physiological and pathological processes such as respiration, transport of $\mathrm{CO}_{2}, \mathrm{pH}$ and $\mathrm{CO}_{2}$ homeostasis, some biosynthetic reactions, calcification and tumorigenicity. ${ }^{2}$
Sixteen isozymes of this zinc-attached enzyme family are defined according to inhibitor differences, catalytic activities and their places in the cell. Some of these isoenzymes are cytosolic (CA I, CA II, CA III, CA VII and CA XIII), some are attached to membrane (CA IV, CA IX, CA XII and CA XIV), two are mitochondrial (CA VA and $(A \mathrm{VB}$ ) and one is secretory (CA VI). CA XV isoform is not expressed in humans and other anthropoids, while expression is very commonly found in rats and other higher vertebrates. ${ }^{3,4}$ Many of this CA isozymes are therapeutic targets to fight some disorders like oedema, glaucoma, obesity, cancer, epilepsy and

*Correspondence: E-mail: mkuzu@agri.edu.tr, Phone: +90 4722156026

Received: 17.03.2016, Accepted: 11.08.2016

๑Turk J Pharm Sci, Published by Galenos Publishing House. 
osteoporosis. Also, it is emphasized that CA inhibitors may be used for treatment of infections caused by protozoa, fungi and bacteria. $^{2}$

Flavanone compounds are antioxidant substances which are widely used. Naringenin is a flavanone compound, and can be found in nature in the leaves, flowers and stems of plants used as herbal teas in various fields of medicine, food chemistry and biochemistry. ${ }^{5}$ As a natural flavonone, naringenin (4',5,7-trihydroxy-flavanone-7-ramnoglucosidet) is found in rich amounts in citrus, tomato, fruits, strawberry, grapefruit and cacao. There is a great deal of research on the antioxidant, anti-tumor, anti-inflammatory and hepato-protective effects of naringenin. Naringenin's structural similarity to silymarin, and quercetin improves its use as an antioxidant against arsenic toxicity and also as a chelate agent. ${ }^{6,7}$ Naringenin is pharmacologically accepted as a potential antioxidant, and its anticarcinogenic, antiaterogenic, hepatoprotective, nephroprotective, and antimutagenic activities have been reported. ${ }^{8,9}$

Lead is a metal found in the air, in many foods, drinking water, soil and thus, also in humans. The increase of lead levels in the body inhibits certain physiological processes and leads to toxicity of the cardiovascular and hematopoietic systems..$^{10,11}$

Although there are studies concerning in vitro inhibition effects of heavy metals on CAs, there are limited data in vivo effects of them. Also, no data on the in vivo effect of naringenin on CA activity has been detected in the literature. Therefore, the aim of this study was to determine the effects of naringenin, lead, and naringenin+lead combination on the activity of rat erythrocyte CA.

\section{EXPERIMENTAL}

\section{Chemicals}

Protein assay reagents and 4-nitrophenylacetate (NPA) were obtained from Sigma-Aldrich Co. The other chemicals were of analytical grade and obtained from Merck.

\section{Preparation of the hemolysate}

Fresh rat blood samles were collected in tubes containing ethylenediamine tetraacetic acid, then centrifuged (15 min, $2.500 x g$ ) and plasma and buffy coat (leucocytes) were removed. The packed red cells were washed three times with physiological serum, homolyzed with 5 volume of ice-cold water and then centrifuged $(10.000 x g$, for $30 \mathrm{~min}$ ) to remove the ghost and intact cells.

\section{Animals and treatment}

Twenty eight healthy adult male Wistar albino rats $(240 \pm 40$ $\mathrm{g}$ body weight) were used in this study. The animals were obtained from Fırat University Experimental Research Centre, Elazığ, Turkey. They have been kept at $21 \pm 1^{\circ} \mathrm{C}$ with a 12 -h light/ dark cycle and have been given a commercial pellet diet (Elazığ Food Company, Elazığ, Turkey) and fresh drinking water ad libitum. Animal use protocol was approved by the National Institute of Health and Local Committee on Animal Research
(Number: 03.03.2011-59). The rats were randomly divided into four groups with each group containing six rats.

First group: Control (C),

Second group: Naringenin alone administered group (N),

Third group: Lead acetate alone administered group ( $L$ ),

Fourth group: Naringenin+Lead acetate $(\mathrm{N}+\mathrm{L})$ administered group.

Naringenin was dissolved in corn oil and administered to animals by gavage at the dose of $50 \mathrm{mg} / \mathrm{kg}$ body weight. Wistar male rats were treated with lead acetate (500 ppm) through drinking water for a period of 4 weeks. The last dose was administered $12 \mathrm{~h}$ before the operation. ${ }^{7,12}$

\section{Protein determination}

Quantitative protein determination was spectrophotometrically measured at $595 \mathrm{~nm}$ according to Bradford's method ${ }^{13}$, with bovine serum albumin being used as a standard.

\section{Esterase activity assay}

The esterase activity was assayed by following the change in absorbance of 4-NPA to 4-nitrophenylate ion at $348 \mathrm{~nm}$ over a period of $3 \mathrm{~min}$ at $25^{\circ} \mathrm{C}$ using a spectrophotometer (BECKMAN COULTER UV-VIS) according to the method described by Verpoorte et al. ${ }^{14}$ The enzymatic reaction, in a total volume of

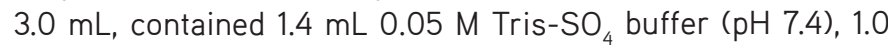

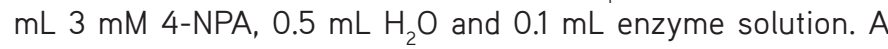
reference measurement was obtained by preparing the same cuvette without enzyme solution.

\section{Statistical analysis}

Statistical analysis data were analyzed using one-way analysis of variance followed by a post hoc Tukey's test. All results were presented as mean \pm standard error mean (SEM). For all analyses, p<0.05 was accepted as statistically significant.

\section{RESULTS}

In this study, we determined CA enzyme average specific activity as $0.006 \pm 0.00023,0.0035 \pm 0.00013,0.0051 \pm 0.00028$ and $0.0038 \pm 0.00013$ in $\mathrm{C}, \mathrm{N}, \mathrm{L}, \mathrm{N}+\mathrm{L}$ groups respectively.

Values are expressed as mean \pm SEM; $n=6$ for each treatment group A (a: p<0.01), (b: p<0.001). Statistical significancy compared to the $C$ group (c: $p<0.001$ ). Statistical significancy compared to the $\mathrm{L}$ group.

Naringenin and lead acetate decreased CA enzymes activity in erythrocyte ( $p<0.001, p<0.01$ ) when compared to the $C$ group. No statistically significant difference was observed in CA enzymes activity among $\mathrm{N}$ and $\mathrm{L}+\mathrm{N}$ groups ( $p>0.05$ ) (Figure 1).

\section{DISCUSSION}

The administration of naringenin to experimental animals grants a protection against illnesses. For example, naringenin antioxidant is known to have protective effects against inflammation, thrombosis, tumorogenesis, atherosclerosis and hypercholesterolemia. ${ }^{6}$ Another study shows that naringenin which is extracted from citrus peels crosses the blood-brain 


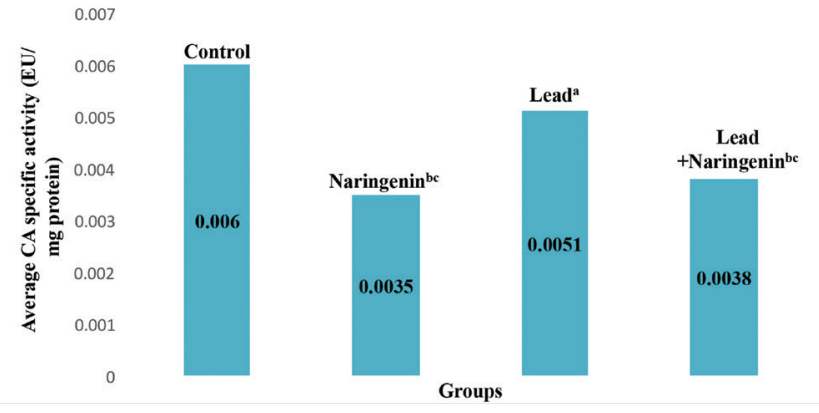

Figure 1. Specific carbonic anhydrase activity of groups

Values are expressed as means \pm standard error; $n=6$ for each treatment group, Statistical significancy compared to the control group. a: $p<0.01$, b: $p<0.001$, Statistical significancy compared to the lead acetate group. c: $p<0.001$

CA: Carbonic anhydrase

barrier in rats. Due to this property, naringenin can be used to repair the nervous system..$^{15}$ Moreover, it is found that naringenin inhibits liver cell leakage, lipid peroxidation and protection oxidation, increases the level of enzymatic and non-enzymatic antioxidants and also inhibits DNA damage. ${ }^{6}$ Naringenin can inhibit iron-dependent Fenton reaction by chelating with iron ions, there by reducing the formation of hydroxyl radicals. Because of the electron providing and radical-binding property of the 4'-hydroxyl group on its ring, naringenin is proven to remove free radicals effectively. This protects the cell against free radical attacks, and inhibits lipid peroxidation. ${ }^{8}$ However, many studies show that various flavonoids strongly inhibit the CA isozymes under in vitro conditions. ${ }^{16,17}$ In the previous study conducted by Ekinci et al. ${ }^{17}$ and co-workers, it was determined that quercetin, apigenin, luteolin and morin which are a flavanone inhibited human CA I and II isozyme with $\mathrm{K}_{\mathrm{i}}$ values $3.6-2.4 \mu \mathrm{M}$; 4.1-2.7 $\mu \mathrm{M} ; 2.2-0,74 \mu \mathrm{M}$ and 12.8-4.4 $\mu \mathrm{M}$, respectively.

Due to the fact that metals reduce the amounts of phosphate, calcium, glycogen and protein in kidneys, fatal results may occur in mammals. ${ }^{18}$ Heavy metals affect humans and particularly the brains of babies during the post-natal stage. Compared to other organs, the forming of the brain and its growth takes longer. Brain growth continues during the post-natal stage.19

Many in vitro and in vivo studies show that reactive oxygen species arising out of lead, namely hydroperoxides, lead to an increase in singlet oxygen, hydrogen peroxide and superoxide radicals. Many studies show that lead changes the composition of fatty acids in the cell membrane structure. It is also known to increase the level of malondialdehyde (MDA) in the liver and MDA is a significant oxidative stress indicator. It is found that puerarin, a flavonoid derivative, reduces the growth of radicals and MDA levels in liver tissues of rats administered lead. ${ }^{20}$ Moreover, it is observed that lipid peroxidation products and oxidative stress increased by a considerable amount in the brain tissues of rats administered 500 ppm lead. ${ }^{12}$ In addition, researchers have frequently reported the effects of heavy metal ions on different enzymes in previous years and inhibition effect of heavy metals on metabolically imported enzyme such as $\mathrm{CA}^{21}$, glucose 6-phopsphate dehydrogenase ${ }^{22}$, cytochrome $\mathrm{P} 450$ reductase $\mathrm{r}^{23}$, glutathione S-transferase ${ }^{24}$ have been determined. For example, Ekinci et al. ${ }^{17}$ and co-workers mentions the inhibition effects of lead, copper, cobalt heavy metals on cytosolic human CA I and II enzyme activities. ${ }^{21}$ Heavy metals have enzyme inhibition property by establishing a bond with the sulfhydryl groups of proteins. ${ }^{25}$

Literature shows that many substances like medical drugs, various metals, anions and pesticides have inhibitory effects on CAs. ${ }^{21,26,27,28}$ In this study, the effects of lead and naringenin were examined. A comparison of the enzyme activity results of the groups shows that both lead and naringenin inhibit the CA enzyme in erythrocytes. This study shows that, compared with CA activity in control group, naringenin is an effective inhibitor. Previous studies also indicate that flavonoids similar to naringenin perform a powerful inhibition on CA. Similarly, lead is also found to inhibit the CA enzyme. It is also evident in the literature that lead and other metal ions also inhibit the CA enzyme. However, the inhibition value of naringenin is found to be higher than that of lead and $L+N$ group. In our previous study, inductively coupled plasma-mass spectrometry device measurements in four different groups show that the lead levels of the control, naringenin, lead and $L+N$ groups are $44.88,36.706,172.36$ and 95.076 ppm respectively. ${ }^{29}$ Because a portion of naringenin reacts with lead in a $\mathrm{L}+\mathrm{N}$ application, the observed inhibition value of the $L+N$ group was found to be lower than that of naringenin.

\section{CONCLUSION}

Consequently, the results obtained from the study showed that lead and naringenin inhibited significantly the CA activity in erythrocytes. In this study, we observed that the interaction between lead and naringenin has no significant impact about inhibition effect of naringenin on CA activity. According to results, it may be said that investigation of naringenin on other CA isozymes and synthesis naringenin derivatives are important to improve new and stronger CA inhibitors.

\section{ACKNOWLEDGEMENTS}

The enzyme kinetics measurement parts were performed in Ağrı İbrahim Çeçen University Central Research Laboratory. This research was supported by the ADYUBAP project, number FEFYL 2011/0015.

Conflict of Interest: No conflict of interest was declared by the authors.

\section{REFERENCES}

1. Supuran CT, Scozzafava A. Applications of carbonic anhydrase inhibitors and activators in therapy. Exp Opin Ther Patents. 2002;12:217-242.

2. Supuran CT. Carbonic anhydrases: novel therapeutic applications for inhibitors and activators. Nat Rev Drug Discov. 2008;7:168-181.

3. Hilvo M, Tolvanen M, Clark A, Shen B, Shah GN, Waheed A, Halmi P, Hanninen M, Hamalainen JM, Vihinen M, Sly WS, Parkkila S. Characterization of CA XV, a new GPlanchored form of carbonic anhydrase. Biochem J. 2005392:83-92. 
4. Supuran CT, Carbonic anhydrases: Catalytic and inhibition mechanisms, distribution and physiological roles carbonic anhydrase. In: Carbonic anhydrase. Its inhibitors and activators. Eds: Supuran CT, Scozzafara Conway J, pp 1-23, CRC Press, London, 2004.

5. Karadag $R$, Böhmer $H$. "Dye analyses using derivate UV-Visible spectrophotometry and fibre-safe extraction with EDTA." Dyes in History and Archaeology. 2001;16:106-118.

6. Kannappan S, Palanisamy N, Anuradha CV. Suppression of hepatic oxidative events and regulation of eNOS expression in the liver by naringenin in fructose administered rats. Eur J Pharmacol. 2010;645:177-184.

7. Jain A, Yadav A, Bozhkov Al, Padalko VI, Flora SJ. Therapeutic efficacy of silymarin and naringenin in reducing arsenic-induced hepatic damage in young rats. Ecotoxicol Environ Saf. 2011;74:607-614.

8. Renugadevi J, Prabu SM. Naringenin protects against cadmium-induced oxidative renal dysfunction in rats. Toxicology. 2009;256:128-134.

9. Ekambaram G, Rajendran P, Magesh V, Sakthisekaran D. Naringenin reduces tumor size and weight lost in $N$-methyl- $N$ '-nitro- $N$ nitrosoguanidine-induced gastric carcinogenesis in rats. Nutr Res. 2008;28:106-112.

10. Annabi Berrahal A, Nehdi A, Hajjaji N, Gharbi N, El-Fazâa S. Antioxidant enzymes activities and bilirubin level in adult rat treated with lead. C R Biol. 2007;330:581-588.

11. Park MS, Cho EJ, Lee SK, Lee EJ, Lee DS, Lee KH, Jeon BH. Korean Red Ginseng Protects Oxidative Injury Caused by Lead Poisoning. J Ginseng Res. 2010;34:132-137.

12. Bennet C, Bettaiya R, Rajanna S, Baker L, Yallapragada PR, Brice JJ, White SL, Bokara KK. Region specific increase in the antioxidant enzymes and lipid peroxidation products in the brain of rats exposed to lead. Free Radic Res. 2007;41:267-273.

13. Bradford MM. A rapid and sensitive method for the quantitation of microgram quantities of protein utilizing the principle of protein-dye binding. Anal Biochem. 1976;72:248-254.

14. Verpoorte JA, Mehta S, Edsall JT. Esterase activities of human carbonic anhydrases B and C. J Biol Chem. 1967;242:4221-4229.

15. Yi LT, Li CF, Zhan X, Cui CC, Xiao F, Zhou LP, Xie Y. Involvement of monoaminergic system in the antidepressant-like effect of the flavonoid naringenin in mice. Prog Neuropsychopharmacol Biol Psychiatry. 2010;34:1223-1228.

16. Maresca A, Temperini C, Vu H, Pham NB, Poulsen SA, Scozzafava A, Quinn RJ, Supuran CT. Non-zinc mediated inhibition of carbonic anhydrases: coumarins are a new class of suicide inhibitors. J Am Chem Soc. 2009;131:3057-3062.

17. Ekinci D, Karagoz L, Ekinci D, Senturk M, Supuran CT. Carbonic anhydrase inhibitors: in vitro inhibition of $\alpha$ isoforms (hCA I, hCA II, bCA III, hCA IV) by flavonoid. J Enzyme Inhib Med Chem. 2013;28:283-288.
18. Loghman-Adham M. Renal effects of environmental and occupational lead exposure. Environ Health Perspect. 1997;105:928-938.

19. Windham B. Effects of toxic metals on learning ability and behavior. 2017.

20. Liu CM, Ma JQ, Sun YZ. Protective role of puerarin on lead-induced alterations of the hepatic glutathione antioxidant system and hyperlipidemia in rats. Food Chem Toxicol. 2011;49:3119-3127.

21. Ekinci D, Beydemir S, Küfrevioğlu OI. In vitro inhibitory effects of some heavy metals on human erythrocyte carbonic anhydrases. J Enzyme Inhib Med Chem. 2007;22:745-750.

22. Hu W, Zhi L, Zhuo MQ, Zhu QL, Zheng JL, Chen QL, Gong Y, Liu CX. Purification and characterization of glucose 6-phosphate dehydrogenase (G6PD) from grass carp (Ctenopharyngodon idella) and inhibition effects of several metal ions on G6PD activity in vitro. Fish Physiol Biochem. 2013;39:637-647.

23. Kuzu M, Çiftci M. Purification and characterization of NADPH-cytochrome P450 reductase from Lake Van fish liver microsomes and investigation of some chemical and metals' effects on the enzyme activity. Turk $J$ Chem. 2015;39:149-158.

24. Çomaklı V, Kuzu M, Demirdağ R. Characterization and Purification of Glutathione S-Transferase from the Liver and Gill Tissues of Ağrı Balık Lake Trout Salmo trutta labrax and the Effects of Heavy Metal lons on Its Activity. J Aquat Anim Health. 2015;27:145-151.

25. Kakkar P, Jaffery FN. Biological markers for metal toxicity. Environ Toxicol Pharmacol. 2005;19:335-349.

26. Comakli V, Ciftci M, Kufrevioglu OI. Effects of some metal ion on rainbow trout erythrocytes glutathione S-transferase enzyme: an in vitro study. J Enzyme Inhib Med Chem. 2013;28:1261-1266.

27. Demirdag R, Yerlikaya E, Kufrevioglu Ol. Purification of Carbonic Anhydrase-II from Sheep Liver and Inhibitory Effects of Some Heavy Metals on Enzyme Activity. J Enzyme Inhib Med Chem. 2012;27:795-799.

28. Demirdağ R, Yerlikaya E, Aksakal E, Küfrevioğlu Ol, Ekinci D. Influence of pesticides on the $\mathrm{pH}$ regulatory enzyme, carbonic anhydrase, from European Seabass liver and bovine erythrocytes. Environ Toxicol Pharmacol. 2012;34:218-222.

29. Demirdag R, Comakli V, Ozkaya A, Sahin Z, Dag U, Yerlikaya E, Kuzu M. Examination of Changes in Enzyme Activities of Erythrocyte Glucose 6-Phosphate Dehydrogenase and 6-Phosphogluconate Dehydrogenase in Rats Given Naringenin and Lead Acetate. J Biochem Mol Toxicol. 2015;29:43-47. 